\title{
Empowerment and Responsiveness Effect on Royal Malaysian Police (RMP) Staffs in Selangor, Malaysia
}

\author{
Mahiswaran Selvanathan ${ }^{1}$, Noor Ain Zeni ${ }^{2}$, Pei Jun $\operatorname{Tan}^{2} \&$ Kantharow Apparavu ${ }^{1}$ \\ ${ }^{1}$ Asia Pacific University, Malaysia \\ ${ }^{2}$ SEGi University, Malaysia \\ Correspondence: Mahiswaran Selvanathan, Asia Pacific University, Malaysia. E-mail: mahiswaran@gmail.com \\ Received: March 24, 2017 \\ Accepted: June 24, 2017 \\ Online Published: July 18, 2017 \\ doi:10.5539/ijbm.v12n8p219 \\ URL: https://doi.org/10.5539/ijbm.v12n8p219
}

\begin{abstract}
This study focuses on service quality in a public sector, Malaysia. This research is aimed at exploring the relationship between empowerment and responsiveness towards work quality, while reviewing customers' satisfaction towards government services, particularly towards the Royal Malaysian Police agency. This paper describes how the Royal Malaysian Police can use their employee work quality through the effectiveness, efficiency and productivity systems as tools to help them reach the highest level of customer satisfaction. Multivariate multiple regression technique was used to measure the relationship between the empowerment and responsiveness towards work quality of the employee. This study concludes that empowerment factor does significantly affect the work quality of the government employees, but their work quality does not satisfy the customers.
\end{abstract}

Keywords: Empowerment, responsiveness, effectiveness, efficiency, productivity and customer satisfaction

\section{Introduction}

There are about 1.6 million people working with the government of Malaysia (Chong, 2016; Lim, 2016). According to Department of Statistics Malaysia (2016), Malaysia civil servants makes up for about 10.8 percent of the overall labor force in Malaysia. Lim Kit Siang, Malaysia Democratic Action Party leader, indicated that Malaysia is ranked as the highest public servants-to-population ratio in Asia-Pacific (Zahid, 2013). In year 2013, one of the ministers in Prime Minister Department contended that the number of public servants is sufficient, and have helped to improve Malaysia's competitiveness (Zahid, 2013). However, this topic continues to be disputed up till today. Economist mentioned in a news article that government can tighten their spending further by cutting down on the "bloated" public service, as the "bloated" public service seemed to be a burden to Malaysia's economic more than an effective method to improve the services in Malaysia (Lim, 2016).

As stated by Mansor and Che Mohd Razali (2010), the role and services of the public sector in Malaysia has been extensively disputed in the parliament as it drives the image and the transformation in economic and social development. It was believed that the quantity within the public sector will provide a satisfactory service to the public.

Nonetheless, Malaysians seem dissatisfied with the delivery of civil services in Malaysia, which is signified by the number of complaints received by the Public Complaints Bureau over the years. In addition, Royal Malaysian Police agency appears to have received the most complaints for years (Public Complaints Bureau, 2016).

Hence, this research is aimed at exploring the relationship between personal psychological factors (empowerment and responsiveness), work quality (effectiveness, efficiency, and productivity), and customer satisfaction, while reviewing customers' satisfaction towards government services, particularly towards Royal Malaysian Police agency. At the same time, this research can also review the effectiveness of police and provide further suggestions in improving government services as benefits for the public.

\section{RESEARCH OBJECTIVE}

- To find the relationship between empowerment and effectiveness.

- To find the relationship between empowerment and efficiency. 
- To find the relationship between empowerment and productivity.

- To find the relationship between responsiveness and effectiveness.

- To find the relationship between responsiveness and efficiency.

- To find the relationship between responsiveness and productivity.

- To find the relationship between effectiveness and customer satisfaction.

- To find the relationship between efficiency and customer satisfaction.

- To find the relationship between productivity and customer satisfaction.

\section{Literature Review}

\subsection{Empowerment}

As reviewed by Polin (2013), empowerment is commonly defined from three approach. They are the power approach (i.e., power sharing between manager and subordinate), participative management approach (i.e., act of sharing management power), and multidimensional approach (multiple internal components that lead to one's feeling of empowerment). In brief, as Lisa (2016) stated, empowerment simply means "becoming powerful" (p. 7), which allows employee to develop and improve continuously. The feeling of empowerment in employee thus becomes an essential factor to accomplish the good ends (Silver, Randolph, \& Seibert, 2006). As stated by Harris (2007), empowerment gives an opportunity to improve customer service providers' decision-making ability while servicing the clients. In addition, Cook and Macaulay (1996) also explained that one of the major advantages of empowerment is the enhanced loyalty of employees through their proprietorship of decision influencing the workplace. This was supported by Namasivayam, Guchait, and Lei (2014), who found significant influence of psychological empowerment on employee's satisfaction, which further gave rise to employee's organization commitment levels as well as customer satisfaction. Similarly, Yagil (2006) also showed that service providers with higher level empowerment experience less burnout, which further lead to higher customer satisfaction as compared to service providers with lower level empowerment.

\subsection{Responsiveness}

Responsiveness refers to "the ability to respond to customer's requirements in a timely and flexible" (Iberahim, Mohd Taufik, Mohd Adzmir, \& Saharuddin, 2015, p. 15). In the service line, responsivness is also defined as one's willingness to assist customer and provide quick service (Brady \& Cronin, 2001; Ismail \& Mohd Yunan, 2016; Kitapci, Akdogan, \& Dortyol, 2014). Daugherty, Ellinger, and Rogers (1995), and Moyes, Cano-Kourouklis, and Scott (2016) found that responsiveness to customers is needed to build and sustain long term relationship with the customers. Daugherty, Ellinger, and Rogers (1995) further described the important relation between the responsiveness and enhanced operating performance (e.g., improved customer satisfaction, quality and productivity improvements, reduced cost, etc.). In the government sector, United Nations (2000) revealed that the wish for reponsiveness and accountability on the part of public servants increased as a result of the growing movement of the country. United Nations further indicated the need to create a policy that allows and facilitates local government to engage in effective local service delivery that is open and responsive.

\section{Work Quality}

According to Selvanathan, Balasubramaniam, and Thanaraju (2012), the implications of work quality is the key factor in achieving customer satisfaction in public sectors. They found that $43 \%$ of the respondents in three different government agencies of selected states in Malaysia were not satisfied with the services provided, in which employees' attitudes appeared to be an important contributing factor that lead to the customer's dissatisfaction. As stated by Prentice (2013), service quality of an organization is unique, and is often dependant on customers' perception of the organization's services. As such, this study will focus on the government sector's work quality following the work quality definition by Selvanathan et al. (2012) and United Nations (2015) that includes three dimensions, which are effectiveness, efficiency, and productivity.

\subsection{Effectiveness}

Yuen and Thai (2015) defined effectiveness of an organization service as the ability to solve any issues promptly, which will has a positive effect on customer satisfaction. Similarly, ISO (International Organization of Standardization) also outlined one of the requirements of a quality management system as the ability of an organization to develop customer satisfaction by applying effective system that includes effective communication with customers (Department of Standards Malaysia, 2009). In addition, United States Office of Personnel Management (1997) also described, timely and adequate feedback as one of the four key components 
of an effective and successful performance management program, which is designed to satisfy the customers' needs as the focus.

\subsection{Efficiency}

Efficiency refers to "the state or quality of being efficient" ("Efficiency", 2016, Def 1), in which efficient means "achieving maximum productivity with minimum wasted effort" ("Efficient", 2016, Def 1). In other words, efficiency may be achieved when one is able to perform or solve a problem in the best possible way with the least amount of time and effort used. As reported by Acharya (2016), organizations have now recognized the importance of efficient consumer response, which can further increase the organization's competitiveness. Similarly, Jha and Kumar (2016) also affirmed that employees' efficiency and productivity are crucial to maintain a business in this new business era. Kumar (1996) further showed significant results on managers' effectiveness and ability to devote waiting time guarantees.

\subsection{Productivity}

Productivity is viewed as the proportion between output and input (Gummesson, 1998). Gummesson (1998) further explained that the focus of productivity of an organization nowadays (and even in future) is no longer on cost reduction but revenue enhancement. In addition, he also viewed productivity as the result of the service provider, the customer, and the interactions between the two parties. This was supported by Royuela and Suriñach (2013) who reported a significant relationship between productivity and work quality (i.e., job characteristics, characteristics of employee, and characteristics of employment).

\section{Customer Satisfaction}

Ramachandran and Chidambaram (2012) indicated that the quality of customer services can be measured by the degree of customer satisfaction. Understanding customers' needs or expectations appeared to be an essential factor to be a successful service provider (Jonas \& Kovesi, 2010). Customer satisfaction was reviewed to have positive relationships with many aspects such as increased customer loyalty (Chang \& Wang, 2011; Keshvari, Farashbandi, \& Geraei, 2015; Lin \& Sun, 2009), increased repurchase intention (Lin \& Lekhawipat, 2014; Liu, 1998), creates positive word-of-mouth (File \& Prince, 1992), and so on. In addition, Adsit, London, Crom, and Jones (1996) also stated that maintaining customer satisfaction can further sustain administrative effectiveness. Besides that, Kumar (1996) also revealed that customers' satisfaction generally depends on the four fundamental performance criteria of the organization. They are product's quality, customer service, sales person's performance, and efficient and effective program delivery. Therefore, it is essential to train the personnel who provides frontline services to the customers' needs with good customer interactions manner.

\section{Methodology and Findings}

In achieving the objectives of the study, 200 questionnaires have been distributed to the Royal Malaysian Police agency in Selangor state, but only 86 have been returned back. The non-probability sampling technique, convenience sampling is used to obtain the data. The data collected is divided into two different groups, whereby data on the personal psychological factors towards work quality have been gathered from the respected employees while questionnaires on customer satisfaction are being congregated from the customers who experienced the services provided by the agency. All variables are measured by the 5-points likert scale questions from: (1) Strongly Disagree, (2) Disagree, (3) Neutral, (4) Agree, and (5) Strongly Agree. Data has been analyzed using SPSS Version 22 and the results are discussed below.

This study chooses the multivariate multiple regression technique to measure the relationship between the psychological factors and work quality of the employee. Hence, multiple regression analysis have been applied to investigate the association between the work quality and customer satisfaction.

\subsection{Normality Assumptions}

Table 1. The Kolmogorov-Smirnov test of normality

\begin{tabular}{llll}
\hline & Statistic & $d f$ & Sig. \\
\hline Effectiveness & .159 & 85 & .000 \\
Efficiency & .183 & 85 & .000 \\
Productivity & .139 & 85 & .000 \\
Customer Satisfaction & .138 & 159 & .000 \\
\hline
\end{tabular}



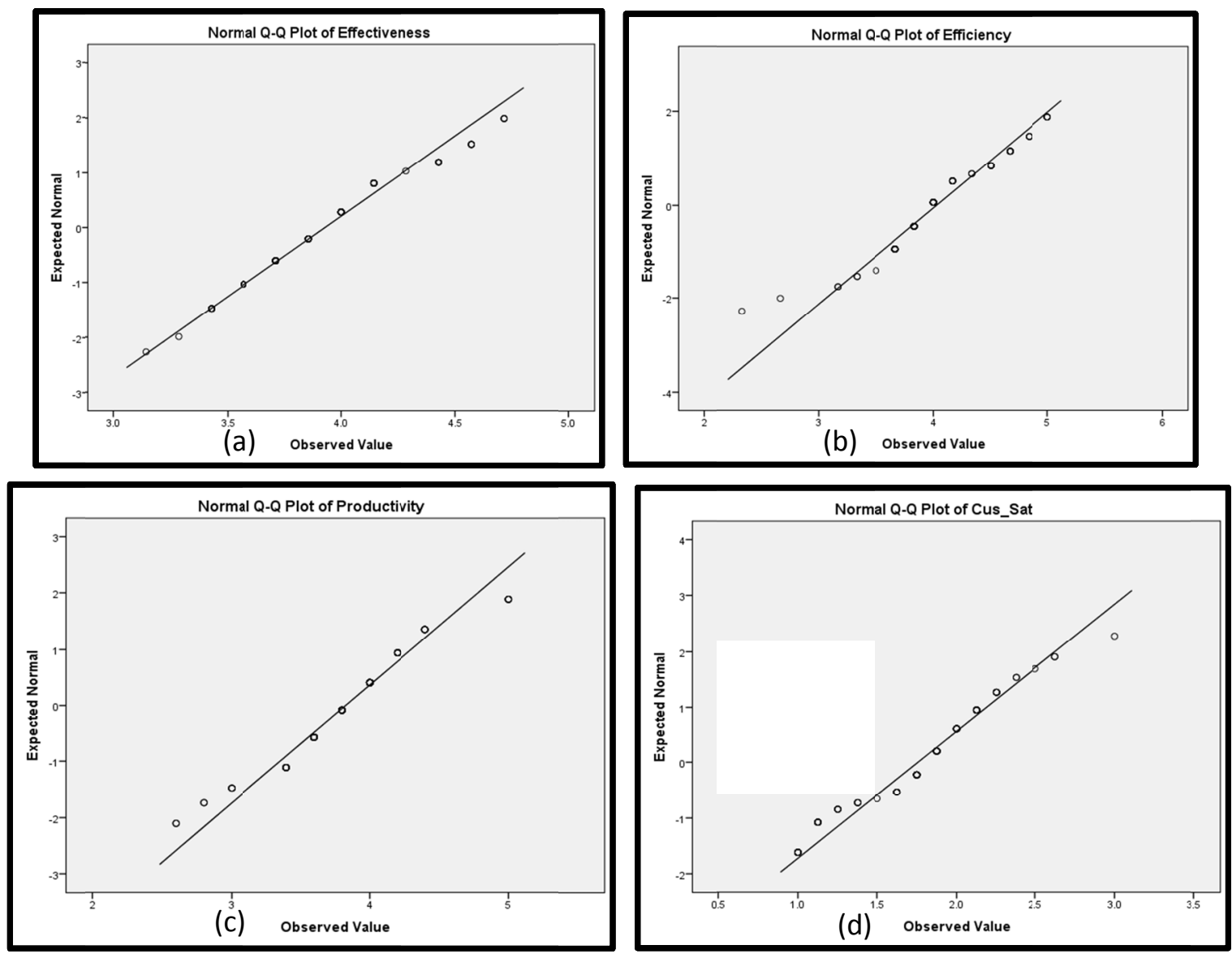

Figure 1. Histogram with normal curve for work quality: (a) Productivity, (b) Efficiency, (c) Effectiveness, and (d) customer satisfaction

Based on Table 1, in the Kolmogorov-Smirnov test for normality, all variables are found to be not normally distributed. Hence, this study approaches pictorial evidence for normality assessment.

The normal Q-Q plots are depicted in Figure 1, it can be seen that the plotting of the expected normal and the observed values did not depart much from the lines. Therefore work quality and customer satisfaction are following the normal distribution. Next, this study examines the association between personal psychological factor and the work quality.

\subsection{Personal Psychological and Work Quality}

Empowerment and responsiveness among the government front-line employees are the personal psychological variables that have been considered as having connection with their work quality. Hence, this study examined the association as shown in Table 2.

Table 2. Multivariate significance test

\begin{tabular}{llllllll}
\hline Effect & & Value & $\mathrm{F}$ & Hypothesis $d f$ & Error $d f$ & Sig. & Partial Eta Squared \\
\hline Intercept & Pillai's Trace & .429 & $20.028^{\mathrm{b}}$ & 3.000 & 80.000 & .000 & .429 \\
& Wilks' Lambda & .571 & $20.028^{\mathrm{b}}$ & 3.000 & 80.000 & .000 & .429 \\
& Hotelling's Trace & .751 & $20.028^{\mathrm{b}}$ & 3.000 & 80.000 & .000 & .429 \\
& Roy's Largest Root & .751 & $20.028^{\mathrm{b}}$ & 3.000 & 80.000 & .000 & .429 \\
& Pillai's Trace & .268 & $9.779^{\mathrm{b}}$ & 3.000 & 80.000 & .000 & .268 \\
& Wilks' Lambda & .732 & $9.779^{\mathrm{b}}$ & 3.000 & 80.000 & .000 & .268 \\
& Hotelling's Trace & .367 & $9.779^{\mathrm{b}}$ & 3.000 & 80.000 & .000 & .268 \\
& Roy's Largest Root & .367 & $9.779^{\mathrm{b}}$ & 3.000 & 80.000 & .000 & .268 \\
\hline
\end{tabular}




\begin{tabular}{lllllllll}
\hline Responsiveness & Pillai's Trace & .006 & $.163^{\mathrm{b}}$ & 3.000 & 80.000 & .921 & .006 \\
& Wilks' Lambda & .994 & $.163^{\mathrm{b}}$ & 3.000 & 80.000 & .921 & .006 \\
& Hotelling's Trace & .006 & $.163^{\mathrm{b}}$ & 3.000 & 80.000 & .921 & .006 \\
& Roy's Largest Root & .006 & $.163^{\mathrm{b}}$ & 3.000 & 80.000 & .921 & .006 \\
\hline
\end{tabular}

The multivariate test of general linear model assesses the significance of each predictors towards the set of dependent variables (Taylor, 2011). Based on Table 4.2, the effect of empowerment is significantly related to at least one of the three components in work quality of the employees. However, responsiveness effect is not significantly related to the work quality.

Table 3. Test of between-subject effects

\begin{tabular}{|c|c|c|c|c|c|c|c|}
\hline \multirow{2}{*}{$\frac{\text { Source }}{\text { Corrected Model }}$} & \multirow{2}{*}{$\begin{array}{l}\text { Dependent Variable } \\
\text { Effectiveness }\end{array}$} & \multirow{2}{*}{$\begin{array}{l}\text { Type III } \\
\text { Squares } \\
3.825^{\mathrm{a}}\end{array}$} & \multirow{2}{*}{$\begin{array}{l}\text { of } \\
\frac{d f}{2}\end{array}$} & \multicolumn{2}{|c|}{ Mean Square F } & \multirow{2}{*}{$\begin{array}{l}\text { Sig. } \\
.000\end{array}$} & \multirow{2}{*}{$\begin{array}{l}\text { Partial Eta Squared } \\
.391\end{array}$} \\
\hline & & & & 1.913 & 26.334 & & \\
\hline & Efficiency & $9.142^{\mathrm{b}}$ & 2 & 4.571 & 34.843 & .000 & .459 \\
\hline & Productivity & $4.469^{\mathrm{c}}$ & 2 & 2.235 & 12.705 & .000 & .237 \\
\hline \multirow[t]{3}{*}{ Intercept } & Effectiveness & 3.721 & 1 & 3.721 & 51.237 & .000 & .385 \\
\hline & Efficiency & .889 & 1 & .889 & 6.780 & .011 & .076 \\
\hline & Productivity & 2.723 & 1 & 2.723 & 15.480 & .000 & .159 \\
\hline \multirow[t]{3}{*}{ Empowerment } & Effectiveness & 1.481 & 1 & 1.481 & 20.392 & .000 & .199 \\
\hline & Efficiency & 2.770 & 1 & 2.770 & 21.119 & .000 & .205 \\
\hline & Productivity & 1.457 & 1 & 1.457 & 8.281 & .005 & .092 \\
\hline \multirow[t]{3}{*}{ Responsiveness } & Effectiveness & .002 & 1 & .002 & .034 & .854 & .000 \\
\hline & Efficiency & .037 & 1 & .037 & .278 & .599 & .003 \\
\hline & Productivity & .007 & 1 & .007 & .038 & .846 & .000 \\
\hline \multirow[t]{3}{*}{ Error } & Effectiveness & 5.955 & 82 & .073 & & & \\
\hline & Efficiency & 10.757 & 82 & .131 & & & \\
\hline & Productivity & 14.423 & 82 & .176 & & & \\
\hline \multirow[t]{3}{*}{ Total } & Effectiveness & 1322.204 & 85 & & & & \\
\hline & Efficiency & 1399.972 & 85 & & & & \\
\hline & Productivity & 1264.600 & 85 & & & & \\
\hline \multirow[t]{3}{*}{ Corrected Total } & Effectiveness & 9.781 & 84 & & & & \\
\hline & Efficiency & 19.899 & 84 & & & & \\
\hline & Productivity & 18.892 & 84 & & & & \\
\hline
\end{tabular}

The corrected model in Table 3 measures the significance of overall model. Therefore, the multivariate general linear model of personal psychological factors is found to be significant for all three variables of work quality. According to the effect interaction and the partial eta criterion (Garson, 2015), empowerment is a significant predictor to respondents' effectiveness, efficiency and productivity in the work quality, controlling other effects in the model. Responsiveness effect is found to be insignificant, while empowerment appeared to be a more important factor in predicting the work quality among the public front-liners.

\subsection{Work Quality and Customer Satisfaction}

Next, the effects of variables considered under work quality of the employees towards customer satisfaction are being examined using the multiple regression analysis. The results are showed in Table 4 and 5 .

Table 4. Model summary

\begin{tabular}{llll} 
ModelR & \multicolumn{3}{c}{ R SquareAdjusted R SquareDurbin-Watson } \\
\hline 1 & $.107^{\mathrm{a}} .011$ & -.025 & 1.380 \\
\hline
\end{tabular}


Table 5. Analysis of variance of dependent variable: customer satisfaction, predictors: (constant), productivity, effectiveness, efficiency

\begin{tabular}{lllllll}
\hline Model & & Sum of Squares & $d f$ & Mean Square & F & Sig. \\
\hline 1 & Regression & .184 & 3 & .061 & .312 & $.817^{\mathrm{b}}$ \\
& Residual & 15.907 & 81 & .196 & & \\
& Total & 16.091 & 84 & & & \\
& & & & & & \\
\end{tabular}

Based on the R-square value in Table 4, there is only a $1.1 \%$ variation in which customers' satisfaction can be explained by the predictors of work quality. No autocorrelation problem exists since the Durbin-Watson value falls within the range of 1.5 to 2.5 (Gul \& Akhtar, 2016), this also proves the assumptions of regression and multivariate technique that random errors are independent. However, the relatively small value of R-square is examined further in analysis of variance (ANOVA) in Table 5. Thus, it is found that the model is not significant.

Table 6. Coefficient analysis

\begin{tabular}{|c|c|c|c|c|c|c|}
\hline \multirow[b]{2}{*}{$\underline{\text { Model }}$} & & \multicolumn{2}{|c|}{ Unstandardized Coefficients } & \multirow{2}{*}{$\begin{array}{l}\text { Standardized Coefficients } \\
\text { Beta }\end{array}$} & \multirow[b]{2}{*}{$t$} & \multirow[b]{2}{*}{ Sig. } \\
\hline & & $\mathrm{B}$ & Std. Error & & & \\
\hline 1 & (Constant) & 2.092 & .583 & & 3.589 & .001 \\
\hline & Effectiveness & -.177 & .185 & -.138 & -.960 & .340 \\
\hline & Efficiency & .084 & .175 & .094 & .481 & .632 \\
\hline & Productivity & .006 & .155 & .006 & .036 & .971 \\
\hline
\end{tabular}

The effect of each predictor towards the customer satisfaction has been inspected through the coefficient analysis Table 6 shows that all variables of work quality: effectiveness, efficiency and productivity effects are not significantly associated with the customers' satisfaction. This has therefore proved that the model does not fit this study.

\section{Conclusion and Recommendation}

In studying the effect of personal psychological factors of the government front-line services towards the work quality, empowerment is a significant predictor to respondents' effectiveness, efficiency and productivity on the work quality, controlling for other effects in the model. Nevertheless, this study also examines the effect of work quality towards customer satisfaction, and it is found that effectiveness, efficiency, and productivity are all having no significant effects on customer satisfaction. Rather, this study concludes that empowerment factor does significantly affect the work quality of the government employees, but their work quality is not related to customer satisfaction. It is advisable that, further research should include rewarding and crediting as the categorical predictor variables in the work quality to explore its relationship towards customer satisfaction. According to Hicks (2015), leaders and managers can improve their employees' performances and indirectly boost the effectiveness of their work by giving out incentives or acknowledging their work. This study also suggests that, there should be appropriate measures on work quality towards customer satisfaction before and after the employee receives certain recognition or token of appreciations.

\section{References}

Acharya, S. (2016). Supply chain management in the government sector. International Journal of Research in Commerce and Management, 7(4), 59-64. Retrieved from http://ijrcm.org.in/

Adsit, D. J., London, M., Crom, S., \& Jones, D. (1996). Relationship between employee attitudes, customer satisfaction and departmental performance. Journal of Management Development, 15(1), 62-75. http://dx.doi.org/10.1108/02621719610107827

Brady, M. K., \& Cronin, J. J. (2001). Some new thoughts on conceptualizing perceived service quality: A hierarchical approach. Journal of Marketing, 65(3), 34-49. http://dx.doi.org/0.1509/jmkg.65.3.34.18334

Chang, H. H., \& Wang, H. W. (2011). The moderating effect of customer perceived value on online shopping behaviour. Online Information Review, 35(3), 333-359. http://dx.doi.org/10.1108/14684521111151414

Chong, P. K. (2016, August 11). Bloated Malaysia civil service presents headache for Najib. Bloomberg Markets. Retrieved from https://www.bloomberg.com/asia

Cook, S., \& Macaulay, S. (1996). The empowered customer service. Training for Quality, 4(1), 7-11. 
http://dx.doi.org/10.1108/09684879610112800

Daugherty, P. J., Ellinger, A. E., \& Rogers, D. S. (1995). Information accessibility: Customer responsiveness and enhanced performance. International Journal of Physical Distribution and Logistics Management, 25(1), 4-17. http://dx.doi.org/10.1108/09600039510080117

Department of Standards Malaysia. (2009). Quality management systems - Requirements (First revision). Retrieved from http://efiles.mediu.edu.my/mye-books/ACD/sirim\%20b.pdf

Department of Statistics Malaysia. (2016). Key statistics of labor force in Malaysia, September 2016. Retrieved from https://www.statistics.gov.my

Dictionary. (2016). Efficient. Retrieved from http://www.dictionary.com/

Efficiency. (2016). In Oxford English online dictionary. Retrieved from https://en.oxforddictionaries.com

Efficient. (2016). In Oxford English online dictionary. Retrieved from https://en.oxforddictionaries.com

File, K. M., \& Prince, R. A. (1992). Positive word-of-mouth: Customer satisfaction and buyer behavior. International Journal of Banking Marketing, 10(1), 25-29. http://dx.doi.org/10.1108/02652329210007867

Garson, G. D. (2015). Statistical associates: Blue book series. Asheboro, North Carolina, USA: Statistical Associates Publishing.

Gul, F., \& Akhtar, N. (2016). Predictors of investor overconfidence in Karachi stock Exchange. Journal of Managerial Sciences, 10(2), 301-315.

Gummesson, E. (1998). Productivity, quality and relationship marketing in service operations. International Journal of Contemporary Hospitality Management, $\quad 10(1), \quad 4-15$. http://dx.doi.org/10.1108/09596119810199282

Harris, E. K. (2007). Customer service: A practical approach. New Jersey: Pearson Prentice Hall.

Hicks, A. (2015, October 30). Top 10 ways to improve employee efficiency. Zenefits Insurance Services: HR Tips \& Trends. from https://www.zenefits.com/blog/top-10-ways-to-improve-employee-efficiency/

Iberahim, H., Mohd Taufik, N. K., Mohd Adzmir, A. S., \& Saharuddin, H. (2015). Customer satisfaction on reliability and responsiveness of self-service technology for retail banking services. Procedia Economics and Finanace, 37(2016), 13-20. http://dx.doi.org/10.1016/S2212-5671(16)30086-7

Ismail, A., \& Mohd Yunan, Y. S. (2016). Service quality as a predictor of customer satisfaction and customer loyalty. Scientific Journal of Logistics, 12(4), 269-283. http://dx.doi.org/10.17270/J.LOG.2016.4.7

Jha, B., \& Kumar, A. (2016). Employee engagement: A strategic tool to enhance performance. DAWN: Journal for Contemporary Research in Management, 3(2) 21-29.

Jonas, T. \& Kovesi, J. (2010). Reliability based Customer Satisfaction Evaluation. Periodica Polytechnica. Social and Management Sciences, 18(1), 3-9. http://dx.doi.org/10.3311/pp.so.2010-1.01

Keshvari, M., Farashbandi, F. Z., \& Geraei, E. (2015). Modelling influential factors on customer loyalty in public libraries: A study of West Iran. The Electronic Library, 33(4), 810-823. http://dx.doi.org/10.1108/EL-10-2013-0185

Kitapci, O., Akdogan, C., \& Dortyol, I. T. (2014). The impact of service quality dimensions on patient satisfaction, repurchase intentions and word-of-mouth communication in the public healthcare industry. $\begin{array}{llll}\text { Procedia Social and Behavioral 161-169. } & \text { Sciences, }\end{array}$ http://dx.doi.org/10.1016/j.sbspro.2014.07.030

Kumar, P. (1996). Customer satisfaction, customer retention, and customer partnerships (Doctoral dissertation). Available from ProQuest Dissertations and Theses Global. (UMI No. 9821776)

Lim, I. (2016, October 24). Economist: Putrajaya can tighten spending further by trimming 'bloated' civil service. Malay Mail Online. Retrieved from http://www.themalaymailonline.com

Lin, C., \& Lekhawipat, W. (2014). Factors affecting online repurchase intention. Industrial Management and Data Systems, 114(4), 597-611. http://dx.doi.org/10.1108/IMDS-10-2013-0432

Lin, G. T. R., \& Sun, C. C. (2009). Factors influencing satisfaction and loyalty in online shopping: An integrated model. Online Information Review, 33(3), 458-475. doi: 10.1108/14684520910969907

Lisa, O. (2016). This thing called empowerment. Administrative Professional Today, 42(12), 7. 
Liu, A. H. (1998). Examining the role of customer value, customer satisfaction, and perceived switching costs: A model of repurchase intention for business-to-business services. (Doctoral dissertation). Available from ProQuest Dissertations and Theses Global. (UMI No. 9835214)

Mansor, N., \& Che Mohd Razali, C. H. (2010). Customers' satisfaction towards counter services of local authorities in Terengganu, Malaysia. Asian Social Science, 6(8), 197-208. Retrieved from www.ccsenet.org/ass

Moyes, D., Cano-Kourouklis, M., \& Scott, J. (2016). Testing the three Rs model of service quality. The TQM Journal, 28(3), 455-466. http://dx.doi.org/10.1108/TQM-02-2015-0026

Namasivayam, K., Guchait, P., \& Lei, P. (2014). The influence of leader empowering behaviors and employee psychological empowerment on customer satisfaction. International Journal of Contemporary Hospitality Management, 26(1), 69-84. http://dx.doi.org/10.1108/14634449710195471

Polin, B. M. (2013). Putting the power back into empowerment: Construct clarification and the incorporation of trust. (Unpublished doctoral dissertation). The Ohio State University, Columbus, OH.

Prentice, C. (2013). Service quality perceptions and customer loyalty in casinos. International Journal of Contemporary Hospitality Management, 25(1), 49-64. http://dx.doi.org/10.1108/09596111311290219

Public Complaints Bureau. (2013). Statistics by year. Retrieved from http://www.pcb.gov.my/en

Ramachandran, A., \& Chidambaram, V. (2012). A review of customer satisfaction towards service quality of banking sector. Periodica Polytechnica Social and Management Sciences, 20(2), 71-79. http://dx.doi.org/10.3311/pp.so.2012-2.02

Royuela, V., \& Suriñach, J. (2013). Quality of work and aggregate productivity. Social Indicators Research, 113(1), 37-66. http://dx.doi.org/10.1007/s11205-012-0081-1

Selvanathan, M., Balasubramaniam, S., \& Thanaraju, P. (2012). Kesan sikap pekerja ke arah kualiti kerja cemerlang [Effects of employees' attitudes toward excellent work quality]. Jurnal Kemanusiaan, 20, 130-146. Retrieved from http://www.management.utm.my/

Silver, S., Randolph, W. A., \& Seibert, S. (2006). Implementing and sustaining empowerment lessons learned from comparison of a for-profit and a nonprofit organization. Journal of Management Inquiry, 15(1), 47-58. http://dx.doi.org/10.1177/1056492605285801

Taylor, A. (2011). Using the GLM Procedure in SPSS [Handbook]. Sydney, Australia: Macquarie University.

United Nations. (2000). Responding to citizens' needs: Local governance and social services for all. Retrieved from http://unpan1.un.org/intradoc/groups/public/documents/un/unpan001598.pdf

United Nations. (2015). Responsive and accountable public governance: 2015 world public sector report. Retrieved from http://workspace.unpan.org/sites/Internet/Documents/UNPAN95253.pdf

United States Office of Personnel Management. (1997). Performance management practitioner series: Improving customer service through effective performance management. Retrieved from file:///F:/Research\%20and\%20Journal/Dr.\%20Mahis\%20SEGi\%20grant/journals/customer_service.pdf

Woo, K. H. (2013). Higher education and the Malaysian public employment. Paper presented at The Asian Conference on Education 2013, Japan. Retrieved from http://iafor.org/archives/offprints/ace2013-offprints/ACE2013_0191.pdf

Yagil, D. (2006). The relationship of service provider power motivation, empowerment and burnout to customer satisfaction. International Journal of Service Industry Management, 17(3), 258-270. http://dx.doi.org/10.1108/09564230610667104

Yuen, K. F., \& Thai, V. V. (2015). Service quality and customer satisfaction in liner shipping. International Journal of Quality and Service Sciences, 7(2/3), 170-183. http://dx.doi.org/10.1108/IJQSS-02-2015-0024

Zahid, S. J. (2013, November 18). Putrajaya defends bloated civil service, says providing jobs. Malay Mail Online. Retrieved from http://www.themalaymailonline.com

\section{Copyrights}

Copyright for this article is retained by the author(s), with first publication rights granted to the journal.

This is an open-access article distributed under the terms and conditions of the Creative Commons Attribution license (http://creativecommons.org/licenses/by/4.0/). 